\title{
Pemilihan Program Penjurusan Pelajaran Seni SD Al-Fath Cirendeu Dengan Metode Analytic Hierarchy Process (AHP)
}

\author{
Teguh Gundara ${ }^{1}$, Sita Anggraeni ${ }^{2}$ \\ ${ }^{1}$ Program Studi Sistem Informasi, ${ }^{2}$ Program Studi Teknik Informatika \\ STMIK Nusa Mandiri Jakarta \\ teguh.gundara@gmail.com
}

\begin{abstract}
Abstrak
Untuk mengetahui seberapa besar minat siswa terhadap beberapa pelajaran seni yang ada di SD Al-Fath Cirendeu maka dibutuhkan Sistem Pendukung Keputusan (SPK) yang dapat membantu memberikan solusi alternatif. Metode yang digunakan dalam SPK pemilihan program penjurusan seni di SD Al-Fath Cirendeu menggunakan Analityc Hierarchy Process $(A H P)$. Pemilihan seni di SD Al-Fath Cirendeu menggunakan metode AHP disajikan dalam bentuk hasil angka perhitungan yang dapat dipertimbangkan lebih lanjut oleh pihak pengambil keputusan. Dengan adanya metode ini dapat mambantu dan memudahkan guruguru seni dalam pemilihan program penjurusan seni dengan tujuan yang tepat sasaran sehingga kegiatan belajar mengajar lebih terfokuskan.
\end{abstract}

Kata Kunci: Sistem Penunjang Keputusan, SD Al-Fath, Pelajaran seni, Metode $A H P$

\section{Abstract}

To know about the student's intention toward some art program in Al-Fath Cirendeu, it will need the Decision Support System (DSS) to help them in an alternative solution. The method that used in DSS in Al-Fath elementary school uses the Analytic Hierarchy Process (AHP) Method. Choices of majors of an art lesson in Al-Fath elementary school Cirendeu is using AHP Method, provide in the term of numbers result in the calculation which can be considered further by teachers. This method can help and make art teachers easily to decide what is the right art lesson, so the teaching and learning activity will be more productive and focus.

Keyword: Decision Support System, Al-Fath Elementary School, Art Programme, AHP Method

\section{PENDAHULUAN}

Salah satu mata pelajaran yang menjadi favorit di SD Al-Fath yaitu program pelajaran seni, mulai dari kelas gitar, keyboard, vocal, teater dan tari. Disetiap tahun ajaran baru siswa kelas 4 diwajibkan hanya memilih satu dari pelajaran seni yang diminati dan tidak diperkenankan untuk pindah atau berganti program seni sampai siswa tersebut lulus sehingga hal tersebut menjadi suatu permasalahan bagi siswa dan juga guru seni yang mengajarnya dalam menentukan keahlian dan bakat apa yang dimiliki dan program pelajaran seni apa yang akan mereka pilih. Berdasarkan hal-hal tersebut, muncul gagasan penulis untuk membuat sebuah metode untuk membantu guru dan siswa maupun pihak-pihak terkait dalam mengambil sebuah keputusan secara cepat dan tepat sesuai dengan kriteria seni yang diinginkan atau setidaknya mendekati kriteria seni yang diinginkan.

Banyaknya metode dalam menyelesaikan masalah pada pengambilan keputusan, maka dipilihlah salah satu 
metode untuk sistem penunjang keputusan pada pemilihan program penjurusan pelajaran seni yaitu Analytic Hierarchy Process (AHP). Menurut Danang \& Nisar, (2017) menyatakan bahwa " $A H P$ merupakan suatu pemodelan untuk membantu pola pikir manusia dalam mengambil suatu keputusan". Dalam model pengambilan keputusan dengan $A H P$ pada dasarnya untuk membantu dan mempermudah guru dan siswa dalam menentukan pemilihan program pelajaran seni.

\section{Rumusan Masalah}

Merujuk pada penelitian yang telah dilakukan dengan guru pelajaran seni sebagai objek penelitian maka penulis mengambil kesimpulan dari hasil penelitian tersebut, yaitu sebagai berikut:

1. Dalam menentukan program pemilihan pelajaran seni, guru dan siswa masih belum objektif dalam mengambil keputusan sehingga pilihan yang diambil tidak sesuai dengan minat, bakat dan kemampuan siswa itu sendiri.

2. Kurang fokusnya kegiatan belajar mengajar dikarenakan pilihan pelajaran seni yang diambil tidak sesuai dengan kriteria yang dimiliki sehingga mempengaruhi pada keaktifan dan potensi siswa.

3. Penulis mencoba untuk membuat metode pengambilan keputusan yang mungkin dapat membantu guru dan siswa dalam pemilihan program penjurusan pelajaran seni sehingga kegiatan belajar mengajar menjadi lebih objektif dan lebih terarah terhadap bakat dan potensi siswa.

\section{Tujuan Penelitian}

Berdasarkan identifikasi masalah yang ada, maksud dan tujuan dari penelitian pemilihan program penjurusan pelajaran seni SD Al-Fath Cirendeu dengan metode $A H P$ ini, antara lain:

1. Menghasilkan sebuah metode dalam pengambilan keputusan bagi guru dan siswa dalam menentukan program penjurusan pelajaran seni melalui kriteria-kriteria yang telah didapatkan.

2. Membantu guru-guru seni dan siswa terkait dalam pemilihan pelajaran seni agar lebih terfokuskan pada saat kegiatan belajar mengajar.

3. Menguji validitas sistem penunjang keputusan dengan metode $A H P$ yang telah dibangun dan mungkin akan dikembangkan sehingga menjadi satu sistem yang dapat dipakai pihak sekolah selanjutnya.

\section{Manfaat Penelitian}

Manfaat dari penelitian ini yaitu memudahkan guru dalam menetapkan pilihan pelajaran seni untuk siswa sesuai dengan kriteria yang dimiliki sehingga lebih terarah dan mempengaruhi bakat dan potensi siswa dalam bidang seni.

\section{LANDASAN TEORI}

Sistem Penunjang Keputusan (SPK) atau Decision Support System (DSS) yang merupakan suatu sistem informasi yang mampu memberikan kemampuan pemecahan masalah maupun kemampuan pengkomunikasian untuk masalah dengan kondisi semi terstruktur dan tidak terstruktur. Hal yang perlu ditekankan di sini adalah keberadaan SPK atau DSS bukan untuk dijadikan sebagai acuan, tetapi untuk menjadi sarana penunjang (tools) bagi mereka yang menggunakannya. Menurut Kusrini dalam Darmanto, E., Latifah, N., \& Susanti, N., (2014) SPK merupakan "Sistem yang membantu pengambil keputusan dengan 
melengkapi mereka dengan informasi dari data yang telah diolah dengan relevan dan diperlukan untuk membuat keputusan tentang suatu masalah dengan lebih cepat dan akurat".

\section{Analityc Hierachy Process (AHP)} yaitu salah satu metode dalam sistem penunjang keputusan. AHP merupakan model yang fleksibel yang memberikan kesempatan bagi perorangan atau kelompok untuk membangun gagasan dan mendefinisikan persoalan dengan cara membuat asumsi mereka masing-masing sehingga memperoleh pemecahan masalah yang diinginkan. Menurut Taufiq \& Fahrozi dalam Agustini, F., (2018) "Metode AHP dikembangkan oleh Thomas L. Saaty sekitar tahun 1970-an untuk mengorganisasikan informasi dan judgment dalam memilih alternatif yang paling disukai".

Pada dasarnya prinsip kerja $A H P$ yaitu menyederhanakan suatu persoalan kompleks yang tidak terstruktur, kemudian tingkat kepentingan setiap variabel diberi nilai numerik secara relatif dibandingkan dengan variabel yang lain. Sehingga memungkinkan pengguna untuk memberikan nilai bobot relatif dari suatu kriteria majemuk atau alternatif majemuk terhadap suatu kriteria secara intuitif, yaitu dengan melakukan perbandingan berpasangan. Dari berbagai pertimbangan tersebut kemudian dilakukan sintesa untuk menetapkan variabel yang memiliki prioritas tinggi dan berperan untuk mempengaruhi hasil pada sistem tersebut.

\section{METODE PENELITIAN}

Perhitungan $A H P$ didasarkan pada matriks prioritas untuk mengekspresikan nilai-nilai penilaian subjektif yang dikaitkan dengan pasangan variabel masing-masing kriteria yang terlibat dalam masalah. Menurut Nurmalasari, \& Pratama, A. A., (2018) Terdapat langkahlangkah sebagai penunjang keputusan menggunakan metode AHP, yaitu sebagai berikut:

\section{Menyusun Struktur Hirarki}

Saat masalah sudah dapat teridentifikasi kemudian dilakukan penyusunan hirarki disertai tujuan yang diinginkan.

\section{Menentukan Prioritas Elemen}

Terdapat beberapa tahapan dalam dalam menentukan prioritas elemen, yaitu sebagai berikut:

a. Langkah pertama dalam menentukan prioritas elemen adalah membuat perbandingan pasangan, yaitu membandingkan elemen secara berpasangan sesuai dengan kriteria yang diberikan.

b. Matriks perbandingan berpasangan diisi dengan menggunakan bilangan untuk mempresentasikan kepentingan relatif dari suatu elemen terhadap elemen lainnya. Berikut adalah tabel format perbandingan berpasangan.

\section{Sintesis (Synthesis of Priority)}

Untuk memperoleh prioritas secara keseluruhan maka pertimbanganpertimbangan terhadap perbandingan berpasangan perlu disintesis. Dalam langkah ini hal-hal yang harus dilakukan adalah:

a. Menjumlahkan nilai-nilai dari setiap kolom pada matriks.

b. Membagi setiap nilai dari kolom dengan total kolom yang bersangkutan untuk memperoleh normalisasi matriks.

c. Menjumlahkan nilai-nilai dari setiap baris dan membaginya dengan jumlah elemen untuk mendapatkan nilai ratarata. 


\section{Mengukur Konsistensi}

Dalam pembuatan keputusan tingkat konsistensi sangat penting untuk diperhatikan karena keputusan yang diambil tidak berdasarkan pertimbangan dengan konsistensi yang rendah dengan nilai maksimal Consistensy Rastio $(C R)$ kurang dari atau sama dengan 0,1 atau 10\%. Hal-hal yang dilakukan dalam langkah ini adalah sebagai berikut:

a. Mengalikan setiap nilai pada kolom pertama dengan prioritas relatif elemen pertama, nilai pada elemen kedua dengan prioritas relatif elemen kedua, dan seterusnya.

b. Menjumlahkan setiap baris pada tabel.

c. Hasil dari penjumlahan baris dibagi elemen prioritas relatif yang bersangkutan.

d. Menjumlahkan hasil bagi diatas dengan banyaknya elemen yang ada hasilnya disebut lamda $(\chi)$ maks.

\section{Menghitung Consistensy Index (CI)}

Untuk menghitung Consistensy Index (CI) terdapat beberapa langkah yang diperlukan agar dapat menentukan nilai CI tersebut, yaitu dengan menggunakan rumus berikut ini:

$$
\mathrm{Cl}=\text { (Lamda maks-n) / n-1 }
$$

Lamda $=($ Jml kriteria $1 \times$ Rata kriteria 1) $+($ Jumlah kriteria $2 \times$ Rata-rata kriteria 2) + dst. $n=$ Banyaknya Elemen

Gambar 1. Rumus Consistensy Index

\section{Menghitung Consistensy Ratio (CR)}

Untuk menghitung Consistensy Ratio (CR) dapat menggunakan rumus sebagai berikut:

\section{$\mathrm{CR}=\mathrm{Cl} / \mathrm{IR}$}

Gambar 2. Rumus Consistensy Ratio

\section{Memeriksa Konsistensi Hirarki}

Jika nilai hirarki lebih dari $10 \%$ maka penilaian data judgement harus diperbaiki, namun jika Consistensy Rasio kurang atau sama dengan 0,1 maka hasil perhitungan bisa dinyatakan benar. Dalam menetapkan nilai Index Random Consistensy (IR) kita dapat mengacu pada tabel nilai dari tabel ketentuan berikut ini:

Tabel 1. Indeks Random Consistensy
\begin{tabular}{cc}
$\begin{array}{c}\text { Ukuran } \\
\text { Matriks }\end{array}$ & Nilai IR \\
\hline 1.2 & 0.00 \\
\hline 3 & 0.58 \\
\hline 4 & 0.90 \\
\hline 5 & 1.12 \\
\hline 6 & 1.24 \\
\hline 7 & 1.32 \\
\hline 8 & 1.41 \\
\hline 9 & 1.45 \\
\hline 10 & 1.49 \\
\hline 11 & 1.51 \\
\hline 12 & 1.48 \\
\hline 13 & 1.56 \\
\hline 14 & 1.57 \\
\hline 15 & 1.59 \\
\hline
\end{tabular}

\section{Menghitung Vektor Eigen Keputusan}

Vektor eigen keputusan merupakan bobot penilaian untuk mendapatkan nilai tunggal yang mewakili sejumlah responden untuk pengambilan keputusan. Untuk memperoleh nilai vektor eigen yaitu dengan menghitung nilai vektor eigen masing-masing alternatif dikalikan dengan vektor eigen kriteria utama. Seperti rumus dibawah ini.

Vektor Eigen keputusan $(\mathrm{VE})=(\mathrm{VE}$ Alternatif 1xVE kriteria 1)+(VE Alternatif 2xVE kriteria 2)+(VE Alternatif ke-n x VE kriteria ke-n).

\section{ANALISIS DAN PERANCANGAN}

Dalam penelitian ini metode yang digunakan yaitu Analityc Hierarchy 
Process (AHP) dengan metode perhitungan matriks berpasangan dengan tujuan memperoleh kriteria yang dapat diukur. tahapan yang dilakukan dalam penelitian ini, yaitu penelitian yang berkaitan dengan teori atau konsep yang akan diteliti dan juga penerapan teori atau konsep yang diolah dengan cara perhitungan manual maupun secara komputasi. Dapat dilihat pada gambar skema dibawah ini:

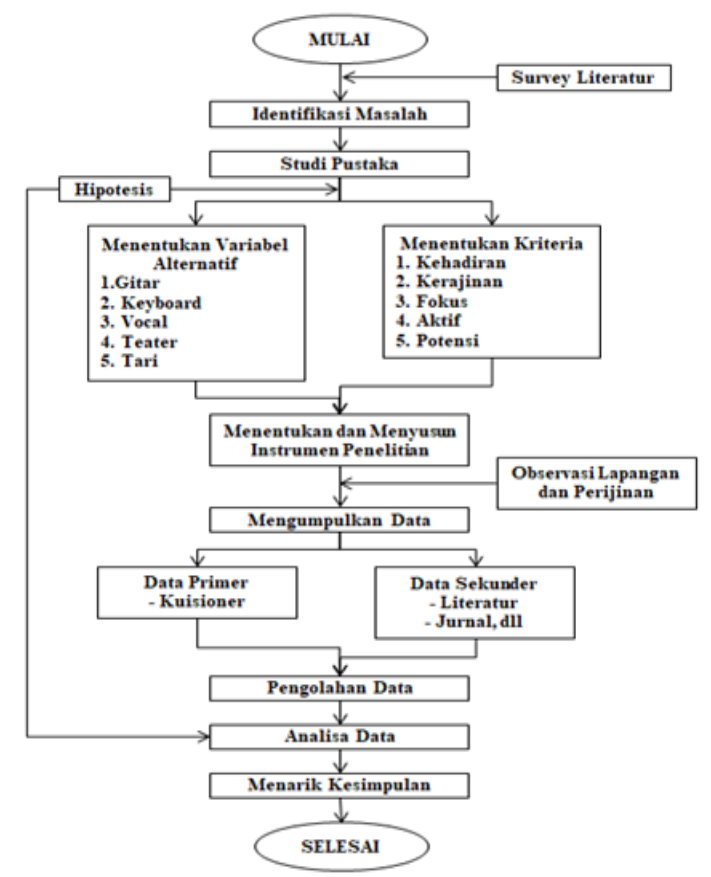

Gambar 3. Tahapan Penelitian

Penjelasan secara umum pada proses penelitian yang dilakukan yaitu sebagai berikut:

\section{Survey Literatur}

Tahapan ini adalah melakukan pengumpulan bahan literatur dan informasi yang berkaitan dengan judul penelitian.

\section{Identifikasi Masalah}

Melakukan identifikasi tentang masalah apa yang akan dibahas berkaitan dengan program pelajaran seni dan permasalahan yang sering muncul pada saat pemilihan program penjurusan pelajaran seni berdasarkan literatur dan informasi yang telah diperoleh.

\section{Studi Pustaka}

Memperpelajari metode yang akan digunakan sebagai kajian teori dalam penelitian ini sehingga dapat mencapai tujuan yang diinginkan.

\section{Hipotesis}

Mengemukakan pertanyaan awal yaitu apakah dengan metode AHP dapat membantu guru dalam menetapkan pilihan pelajaran seni untuk siswa yang sesuai dengan kriteria yang dimiliki.

\section{Menentukan Variabel dan Sumber Data}

Menentukan variabel alternatif dari pemilihan penjurusan pelajaran seni dari mata pelajaran seni yang ada yaitu gitar, keyboard, vocal, teater, tari. Dilanjutkan dengan menentukan kriteria-kriteria yang dibutuhkan untuk diolah kedalam metode yang digunakan diantaranya adalah kehadiran, kerajinan, fokus, aktif dan potensi.

\section{Menentukan dan Menyusun \\ Instrumen Penelitian}

Menentukan pihak atau guru seni yang berkompeten untuk diwawancarai dengan menggunakan kuisioner. Bentuk kuisioner disusun begitu sederhana yaitu berupa ceklis perbandingan kriteria terhadap program pemilihan seni.

\section{Observasi Lapangan dan Perijinan}

Pada tahap ini adalah melakukan pencarian sumber data dan perijinan kepada pihak terkait dan juga guru seni yang berkompeten untuk mengisi 
kuisioner sederhana berdasarkan kriteriakriteria yang telah ditentukan.

\section{Mengumpulkan Data}

Melakukan wawancara terhadap guru seni untuk mendapatkan data-data yang nantinya akan diolah kedalam metode AHP untuk mendapatkan hasil atau tujuan yang diinginkan. Tahap ini dilakukan bersamaan dengan observasi dan perijinan untuk menghemat waktu, biaya dan tenaga.

\section{Pengolahan Data}

Mengolah data yang telah diperoleh dari hasil observasi dan pengumpulan data dengan menggunakan metode $A H P$ melalui perhitungan manual dengan Microsoft Excel 2010 dan kemudian menggunakan software Expert Choice 11 sebagai perbandingan hasil antara perhitungan manual dan komputasi.

\section{Analisa Data}

Hasil pengolahan data antara manual dan komputasi kemudian dianalisa berdasarkan hasil penelitian dan metode yang digunakan.

\section{Menarik Kesimpulan}

Tahap ini bertujuan untuk mengambil kesimpulan berdasarkan analisa data yang kemudian diperiksa kembali apakah sesuai dengan maksud dan tujuan penelitian dari metode yang digunakan.

\section{IMPLEMENTASI DAN PEMBAHASAN}

\section{Pengolahan Data Menggunakan Perhitungan AHP}

\section{A. Menyusun Struktur Hirarki Seni}

Pada penelitian ini penulis mengambil 5 kriteria yang diambil berdasarkan hasil pertimbangan dari wawancara yang telah dilakukan dengan koordinator guru seni dan observasi langsung pada saat kegiatan belajar mengajar pelajaran seni, kriteriakriteria tersebut adalah kehadiran, kerajinan, fokus, aktif, potensi, dan untuk alternatifnya penulis mengambil dari mata pelajaran seni yang tersedia di SD Al-Fath Cirendeu yaitu gitar, vocal, keyboard, teater, tari. Kriteria dan alternatif pada pemilihan program penjurusan pelajaran seni di SD Al-Fath Cirendeu dijelaskan pada gambar struktur hirarki berikut ini:

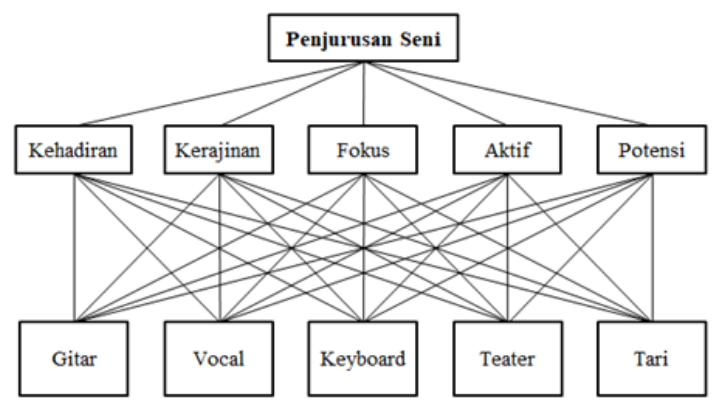

Gambar 4. Hirarki Pemilihan Seni

\section{B. Menentukan Prioritas Elemen}

Langkah kedua yaitu memberi nilai preferensi perbandingan terhadap kriteria dan alternatif, untuk nilai itu sendiri telah ditentukan nilainya sesuai dengan skala nilai bawaan dari metode $A H P$ yang dinamakan skala perbandingan berpasangan. Nilai-nilai itu dapat dilihat pada tabel berikut ini:

Tabel 2. Skala Perbandingan Berpasangan

\begin{tabular}{|c|l|}
\hline Nilai & \multicolumn{1}{|c|}{ Keterangan } \\
\hline $\mathbf{1}$ & $\begin{array}{l}\text { Kedua element sama } \\
\text { pentingnya }\end{array}$ \\
\hline $\mathbf{3}$ & $\begin{array}{l}\text { Elemen yang satu sedikit lebih } \\
\text { penting daripada elemen } \\
\text { lainnya }\end{array}$ \\
\hline $\mathbf{5}$ & $\begin{array}{l}\text { Elemen yang satu lebih penting } \\
\text { daripada elemen lainnya }\end{array}$ \\
\hline $\mathbf{7}$ & $\begin{array}{l}\text { Satu elemen jelas lebih mutlak } \\
\text { penting daripada elemen } \\
\text { lainnya }\end{array}$ \\
\hline $\mathbf{9}$ & $\begin{array}{l}\text { Satu elemen mutlak penting } \\
\text { daripada elemen lainnya }\end{array}$ \\
\hline $\mathbf{2 , 4 , 6 , 8}$ & $\begin{array}{l}\text { Nilai-nilai antara dua nilai } \\
\text { pertimbangan-pertimbangan } \\
\text { yang berdekatan }\end{array}$ \\
\hline
\end{tabular}


Tabel 3. Perbandingan Kriteria Utama

\begin{tabular}{|c|c|c|c|c|c|}
\hline $\begin{array}{c}\text { Kriteri } \\
\text { a }\end{array}$ & $\begin{array}{c}\text { Kehadi } \\
\text { ran }\end{array}$ & $\begin{array}{c}\text { Keraji } \\
\text { nan }\end{array}$ & $\begin{array}{c}\text { Fok } \\
\text { us }\end{array}$ & $\begin{array}{c}\text { Ak } \\
\text { tif }\end{array}$ & $\begin{array}{c}\text { Pote } \\
\text { nsi }\end{array}$ \\
\hline $\begin{array}{c}\text { Kehadi } \\
\text { ran }\end{array}$ & 1,000 & 1,000 & $\begin{array}{c}7,00 \\
0\end{array}$ & $\begin{array}{c}3,0 \\
00\end{array}$ & $\begin{array}{c}5,00 \\
0\end{array}$ \\
\hline $\begin{array}{c}\text { Keraji } \\
\text { nan }\end{array}$ & 1,000 & 1,000 & $\begin{array}{c}5,00 \\
0\end{array}$ & $\begin{array}{c}3,0 \\
00\end{array}$ & $\begin{array}{c}7,00 \\
0\end{array}$ \\
\hline Fokus & 0,143 & 0,200 & $\begin{array}{c}1,00 \\
0\end{array}$ & $\begin{array}{c}0,3 \\
33\end{array}$ & $\begin{array}{c}3,00 \\
0\end{array}$ \\
\hline Aktif & 0,333 & 0,333 & $\begin{array}{c}3,00 \\
0\end{array}$ & $\begin{array}{c}1,0 \\
00\end{array}$ & $\begin{array}{c}3,00 \\
0\end{array}$ \\
\hline Potensi & 0,200 & 0,143 & $\begin{array}{c}0,33 \\
3\end{array}$ & $\begin{array}{c}0,3 \\
33\end{array}$ & $\begin{array}{c}1,00 \\
0\end{array}$ \\
\hline Jumlah & 2,676 & 2,676 & $\begin{array}{c}16,3 \\
33\end{array}$ & $\begin{array}{c}7,6 \\
67\end{array}$ & $\begin{array}{c}19,0 \\
00\end{array}$ \\
\hline
\end{tabular}

Tabel 4. Perbandingan Kriteria Kehadiran

\begin{tabular}{|c|c|c|c|c|c|}
\hline $\begin{array}{c}\text { Kehadir } \\
\text { an }\end{array}$ & $\begin{array}{c}\text { Gita } \\
\mathrm{r}\end{array}$ & $\begin{array}{c}\text { Voca } \\
1\end{array}$ & $\begin{array}{c}\text { Keyboa } \\
\mathrm{rd}\end{array}$ & $\begin{array}{c}\text { Teat } \\
\text { er }\end{array}$ & Tari \\
\hline Gitar & $\begin{array}{c}1,00 \\
0\end{array}$ & $\begin{array}{c}2,00 \\
0\end{array}$ & 3,000 & $\begin{array}{c}1,00 \\
0\end{array}$ & $\begin{array}{c}1,00 \\
0\end{array}$ \\
\hline Vocal & $\begin{array}{c}0,50 \\
0\end{array}$ & $\begin{array}{c}1,00 \\
0\end{array}$ & 0,333 & $\begin{array}{c}0,33 \\
3\end{array}$ & $\begin{array}{c}0,33 \\
3\end{array}$ \\
\hline $\begin{array}{c}\text { Keyboar } \\
\mathrm{d}\end{array}$ & $\begin{array}{c}0,33 \\
3\end{array}$ & $\begin{array}{c}3,00 \\
0\end{array}$ & 1,000 & $\begin{array}{c}0,33 \\
3\end{array}$ & $\begin{array}{c}1,00 \\
0\end{array}$ \\
\hline Teater & $\begin{array}{c}1,00 \\
0\end{array}$ & $\begin{array}{c}3,00 \\
0\end{array}$ & 3,000 & $\begin{array}{c}1,00 \\
0\end{array}$ & $\begin{array}{c}3,00 \\
0\end{array}$ \\
\hline Tari & $\begin{array}{c}1,00 \\
0\end{array}$ & $\begin{array}{c}3,00 \\
0\end{array}$ & 1,000 & $\begin{array}{c}0,33 \\
3\end{array}$ & $\begin{array}{c}1,00 \\
0\end{array}$ \\
\hline Jumlah & $\begin{array}{c}3,83 \\
3\end{array}$ & $\begin{array}{c}12,0 \\
00\end{array}$ & 8,333 & $\begin{array}{c}2,99 \\
9\end{array}$ & $\begin{array}{c}6,33 \\
3\end{array}$ \\
\hline
\end{tabular}

Tabel 5. Perbandingan Kriteria Kerajinan

\begin{tabular}{|c|c|c|c|c|c|}
\hline $\begin{array}{c}\text { Kerajin } \\
\text { an }\end{array}$ & $\begin{array}{c}\text { Gita } \\
\mathrm{r}\end{array}$ & $\begin{array}{c}\text { Voc } \\
\mathrm{al}\end{array}$ & $\begin{array}{c}\text { Keyboa } \\
\mathrm{rd}\end{array}$ & $\begin{array}{c}\text { Teat } \\
\text { er }\end{array}$ & Tari \\
\hline Gitar & $\begin{array}{c}1,00 \\
0\end{array}$ & $\begin{array}{c}3,00 \\
0\end{array}$ & 3,000 & $\begin{array}{c}1,00 \\
0\end{array}$ & $\begin{array}{c}1,00 \\
0\end{array}$ \\
\hline Vocal & $\begin{array}{c}0,33 \\
3\end{array}$ & $\begin{array}{c}1,00 \\
0\end{array}$ & 1,000 & $\begin{array}{c}1,00 \\
0\end{array}$ & $\begin{array}{c}1,00 \\
0\end{array}$ \\
\hline $\begin{array}{c}\text { Keyboar } \\
\mathrm{d}\end{array}$ & $\begin{array}{c}0,33 \\
3\end{array}$ & $\begin{array}{c}1,00 \\
0\end{array}$ & 1,000 & $\begin{array}{c}0,33 \\
3\end{array}$ & $\begin{array}{c}1,00 \\
0\end{array}$ \\
\hline Teater & $\begin{array}{c}1,00 \\
0\end{array}$ & $\begin{array}{c}1,00 \\
0\end{array}$ & 3,000 & $\begin{array}{c}1,00 \\
0\end{array}$ & $\begin{array}{c}3,00 \\
0\end{array}$ \\
\hline Tari & $\begin{array}{c}1,00 \\
0\end{array}$ & $\begin{array}{c}1,00 \\
0\end{array}$ & 1,000 & $\begin{array}{c}0,33 \\
3\end{array}$ & $\begin{array}{c}1,00 \\
0\end{array}$ \\
\hline Jumlah & $\begin{array}{c}3,66 \\
6\end{array}$ & $\begin{array}{c}7,00 \\
0\end{array}$ & 9,000 & $\begin{array}{c}3,66 \\
6\end{array}$ & $\begin{array}{c}7,00 \\
0\end{array}$ \\
\hline
\end{tabular}

Tabel 6. Perbandingan Kriteria Fokus

\begin{tabular}{|c|c|c|c|c|c|}
\hline Fokus & Gitar & $\begin{array}{c}\text { Voca } \\
1\end{array}$ & $\begin{array}{c}\text { Keyboa } \\
\text { rd }\end{array}$ & $\begin{array}{c}\text { Teat } \\
\text { er }\end{array}$ & Tari \\
\hline Gitar & $\begin{array}{c}1,00 \\
0\end{array}$ & $\begin{array}{c}0,33 \\
3\end{array}$ & 0,333 & $\begin{array}{c}0,33 \\
3\end{array}$ & $\begin{array}{c}0,33 \\
3\end{array}$ \\
\hline
\end{tabular}

\begin{tabular}{|c|c|c|c|c|c|} 
Vocal & $\begin{array}{c}3,00 \\
0\end{array}$ & $\begin{array}{c}1,00 \\
0\end{array}$ & 0,333 & $\begin{array}{c}0,33 \\
3\end{array}$ & $\begin{array}{c}0,33 \\
3\end{array}$ \\
\hline $\begin{array}{c}\text { Keyboa } \\
\text { rd }\end{array}$ & $\begin{array}{c}3,00 \\
0\end{array}$ & $\begin{array}{c}3,00 \\
0\end{array}$ & 1,000 & $\begin{array}{c}1,00 \\
0\end{array}$ & $\begin{array}{c}0,33 \\
3\end{array}$ \\
\hline Teater & $\begin{array}{c}3,00 \\
0\end{array}$ & $\begin{array}{c}3,00 \\
0\end{array}$ & 1,000 & $\begin{array}{c}1,00 \\
0\end{array}$ & $\begin{array}{c}0,33 \\
3\end{array}$ \\
\hline Tari & $\begin{array}{c}3,00 \\
0\end{array}$ & $\begin{array}{c}3,00 \\
0\end{array}$ & 3,000 & $\begin{array}{c}3,00 \\
0\end{array}$ & $\begin{array}{c}1,00 \\
0\end{array}$ \\
\hline Jumlah & $\begin{array}{c}13,0 \\
00\end{array}$ & $\begin{array}{c}10,3 \\
33\end{array}$ & 5,666 & $\begin{array}{c}5,66 \\
6\end{array}$ & $\begin{array}{c}2,33 \\
3\end{array}$ \\
\hline
\end{tabular}

Tabel 7. Perbandingan Kriteria Potensi

\begin{tabular}{|c|c|c|c|c|c|}
\hline Aktif & $\begin{array}{c}\text { Gita } \\
\mathrm{r}\end{array}$ & $\begin{array}{c}\text { Voc } \\
\mathrm{al}\end{array}$ & $\begin{array}{c}\text { Keyboa } \\
\mathrm{rd}\end{array}$ & $\begin{array}{c}\text { Teate } \\
\mathrm{r}\end{array}$ & Tari \\
\hline Gitar & $\begin{array}{c}1,00 \\
0\end{array}$ & $\begin{array}{c}3,00 \\
0\end{array}$ & 3,000 & 3,000 & 3,000 \\
\hline Vocal & $\begin{array}{c}0,33 \\
3\end{array}$ & $\begin{array}{c}1,00 \\
0\end{array}$ & 1,000 & 3,000 & 3,000 \\
\hline $\begin{array}{c}\text { Keyboa } \\
\text { rd }\end{array}$ & $\begin{array}{c}0,33 \\
3\end{array}$ & $\begin{array}{c}1,00 \\
0\end{array}$ & 1,000 & 3,000 & 3,000 \\
\hline Teater & $\begin{array}{c}0,33 \\
3\end{array}$ & $\begin{array}{c}0,33 \\
3\end{array}$ & 0,333 & 1,000 & 1,000 \\
\hline Tari & $\begin{array}{c}0,33 \\
3\end{array}$ & $\begin{array}{c}0,33 \\
3\end{array}$ & 0,333 & 1,000 & 1,000 \\
\hline Jumlah & $\begin{array}{c}2,33 \\
3\end{array}$ & $\begin{array}{c}5,66 \\
6\end{array}$ & 5,666 & $\begin{array}{c}11,00 \\
0\end{array}$ & $\begin{array}{c}11,00 \\
0\end{array}$ \\
\hline
\end{tabular}

\section{Sintesis}

Setelah menemukan hasil dari matriks perbandigan berpasangan, langkah yang dilakukan selanjutnya yaitu menemukan eigen vektor atau nilai rata-rata (local priority) dari tiap-tiap matriks perbandingan berpasangan.

Tabel 8. Eigen Kriteria Utama

\begin{tabular}{|c|c|c|c|c|c|c|}
\hline $\begin{array}{l}\text { Krite } \\
\text { ria }\end{array}$ & $\begin{array}{l}\text { Keha } \\
\text { diran }\end{array}$ & $\begin{array}{l}\text { Keraj } \\
\text { inan }\end{array}$ & $\begin{array}{l}\text { Fo } \\
\text { kus }\end{array}$ & $\begin{array}{c}\text { Ak } \\
\text { tif }\end{array}$ & $\begin{array}{l}\text { Pot } \\
\text { ensi }\end{array}$ & $\begin{array}{l}\text { Vek } \\
\text { tor } \\
\text { Eig } \\
\text { en }\end{array}$ \\
\hline $\begin{array}{l}\text { Keha } \\
\text { diran }\end{array}$ & 0,374 & 0,374 & $\begin{array}{l}0,4 \\
29 \\
\end{array}$ & $\begin{array}{c}0,3 \\
91 \\
\end{array}$ & $\begin{array}{c}0,26 \\
3\end{array}$ & $\begin{array}{c}0,3 \\
66 \\
\end{array}$ \\
\hline $\begin{array}{c}\text { Keraj } \\
\text { inan }\end{array}$ & 0,374 & 0,374 & $\begin{array}{c}0,3 \\
06\end{array}$ & $\begin{array}{c}0,3 \\
91 \\
\end{array}$ & $\begin{array}{c}0,36 \\
8\end{array}$ & $\begin{array}{c}0,3 \\
63 \\
\end{array}$ \\
\hline Fokus & 0,053 & 0,075 & $\begin{array}{c}0,0 \\
61 \\
\end{array}$ & $\begin{array}{l}0,0 \\
43 \\
\end{array}$ & $\begin{array}{c}0,15 \\
8 \\
\end{array}$ & $\begin{array}{l}0,0 \\
78 \\
\end{array}$ \\
\hline Aktif & 0,125 & 0,125 & $\begin{array}{l}0,1 \\
84\end{array}$ & $\begin{array}{l}0,1 \\
30\end{array}$ & $\begin{array}{c}0,15 \\
8\end{array}$ & $\begin{array}{r}0,1 \\
44\end{array}$ \\
\hline $\begin{array}{c}\text { Poten } \\
\text { si } \\
\end{array}$ & 0,075 & 0,053 & $\begin{array}{l}0,0 \\
20\end{array}$ & $\begin{array}{c}0,0 \\
43 \\
\end{array}$ & $\begin{array}{c}0,05 \\
3 \\
\end{array}$ & $\begin{array}{l}0,0 \\
49 \\
\end{array}$ \\
\hline \multicolumn{6}{|c|}{ Jumlah } & 1 \\
\hline
\end{tabular}


Dari nilai vektor eigen menunjukkan bahwa:

1. Kriteria kehadiran memiliki prioritas tertinggi dengan bobot 0,366

2. Kriteria kerajinan memiliki prioritas kedua dengan bobot 0,363

3. Kriteria aktif memiliki prioritas ketiga dengan bobot 0,144

4. Kriteria fokus memiliki prioritas keempat dengan bobot 0,078

5. Kriteria potensi memiliki prioritas terendah dengan bobot 0,049

Tabel 9. Eigen Kriteria Kehadiran

\begin{tabular}{|c|c|c|c|c|c|c|}
\hline $\begin{array}{c}\text { Kehadi } \\
\text { ran }\end{array}$ & $\begin{array}{l}\text { Git } \\
\text { ar }\end{array}$ & $\begin{array}{l}\text { Vo } \\
\text { cal }\end{array}$ & $\begin{array}{c}\text { Keybo } \\
\text { ard }\end{array}$ & $\begin{array}{l}\text { Tea } \\
\text { ter }\end{array}$ & $\begin{array}{c}\text { Tar } \\
\mathrm{i}\end{array}$ & $\begin{array}{c}\text { Vek } \\
\text { tor } \\
\text { Eige } \\
\text { n }\end{array}$ \\
\hline Gitar & $\begin{array}{c}0,2 \\
61 \\
\end{array}$ & $\begin{array}{l}0,1 \\
67 \\
\end{array}$ & 0,360 & $\begin{array}{l}0,3 \\
33 \\
\end{array}$ & $\begin{array}{l}0,1 \\
58 \\
\end{array}$ & $\begin{array}{c}0,25 \\
6\end{array}$ \\
\hline Vocal & $\begin{array}{l}0,1 \\
30 \\
\end{array}$ & $\begin{array}{l}0,0 \\
83 \\
\end{array}$ & 0,040 & $\begin{array}{l}0,1 \\
11 \\
\end{array}$ & $\begin{array}{l}0,0 \\
53\end{array}$ & $\begin{array}{c}0,08 \\
3\end{array}$ \\
\hline $\begin{array}{c}\text { Keyboa } \\
\text { rd } \\
\end{array}$ & $\begin{array}{l}0,0 \\
87 \\
\end{array}$ & $\begin{array}{l}0,2 \\
50 \\
\end{array}$ & 0,120 & $\begin{array}{l}0,1 \\
11 \\
\end{array}$ & $\begin{array}{l}0,1 \\
58 \\
\end{array}$ & $\begin{array}{c}0,14 \\
5\end{array}$ \\
\hline Teater & $\begin{array}{l}0,2 \\
61 \\
\end{array}$ & $\begin{array}{l}0,2 \\
50 \\
\end{array}$ & 0,360 & $\begin{array}{l}0,3 \\
33 \\
\end{array}$ & $\begin{array}{l}0,4 \\
74 \\
\end{array}$ & $\begin{array}{c}0,33 \\
6 \\
\end{array}$ \\
\hline Tari & $\begin{array}{l}0,2 \\
61 \\
\end{array}$ & $\begin{array}{l}0,2 \\
50 \\
\end{array}$ & 0,120 & $\begin{array}{l}0,1 \\
11 \\
\end{array}$ & $\begin{array}{l}0,1 \\
58 \\
\end{array}$ & $\begin{array}{c}0,18 \\
0\end{array}$ \\
\hline \multicolumn{6}{|c|}{ Jumlah } & 1 \\
\hline
\end{tabular}

Tabel 10. Eigen Kriteria Kerajinan

\begin{tabular}{|c|c|c|c|c|c|c|}
\hline $\begin{array}{c}\text { Keraji } \\
\text { nan }\end{array}$ & $\begin{array}{l}\text { Git } \\
\text { ar }\end{array}$ & $\begin{array}{l}\text { Vo } \\
\text { cal }\end{array}$ & $\begin{array}{c}\text { Keybo } \\
\text { ard }\end{array}$ & $\begin{array}{l}\text { Tea } \\
\text { ter }\end{array}$ & $\begin{array}{c}\text { Tar } \\
\mathrm{i}\end{array}$ & $\begin{array}{c}\text { Vekt } \\
\text { or } \\
\text { Eige } \\
\text { n }\end{array}$ \\
\hline Gitar & $\begin{array}{l}0,2 \\
31 \\
\end{array}$ & $\begin{array}{c}0,4 \\
29 \\
\end{array}$ & 0,143 & $\begin{array}{c}0,27 \\
3\end{array}$ & $\begin{array}{l}0,1 \\
43 \\
\end{array}$ & $\begin{array}{c}0,24 \\
4\end{array}$ \\
\hline Vocal & $\begin{array}{l}0,0 \\
77\end{array}$ & $\begin{array}{c}0,1 \\
43 \\
\end{array}$ & 0,143 & $\begin{array}{c}0,27 \\
3\end{array}$ & $\begin{array}{l}0,1 \\
43 \\
\end{array}$ & $\begin{array}{c}0,15 \\
6\end{array}$ \\
\hline $\begin{array}{c}\text { Keybo } \\
\text { ard }\end{array}$ & $\begin{array}{l}0,2 \\
31\end{array}$ & $\begin{array}{c}0,1 \\
43\end{array}$ & 0,143 & $\begin{array}{c}0,09 \\
1\end{array}$ & $\begin{array}{l}0,1 \\
43\end{array}$ & $\begin{array}{c}0,15 \\
00\end{array}$ \\
\hline Teater & $\begin{array}{c}0,2 \\
31\end{array}$ & $\begin{array}{c}0,1 \\
43\end{array}$ & 0,429 & $\begin{array}{c}0,27 \\
3\end{array}$ & $\begin{array}{l}0,4 \\
29\end{array}$ & $\begin{array}{c}\mathbf{0 , 3 0} \\
1\end{array}$ \\
\hline Tari & $\begin{array}{l}0,2 \\
31\end{array}$ & $\begin{array}{c}0,1 \\
43\end{array}$ & 0,143 & $\begin{array}{c}0,09 \\
1\end{array}$ & $\begin{array}{l}0,1 \\
43\end{array}$ & $\begin{array}{c}0,15 \\
01\end{array}$ \\
\hline \multicolumn{6}{|c|}{ Jumlah } & 1 \\
\hline
\end{tabular}

Tabel 11. Eigen Kriteria Fokus

\begin{tabular}{|c|c|c|c|c|c|c|}
\hline Fokus & $\begin{array}{c}\text { Git } \\
\text { ar }\end{array}$ & $\begin{array}{c}\text { Vo } \\
\text { cal }\end{array}$ & $\begin{array}{c}\text { Keybo } \\
\text { ard }\end{array}$ & $\begin{array}{c}\text { Tea } \\
\text { ter }\end{array}$ & $\begin{array}{c}\text { Tar } \\
\text { i }\end{array}$ & $\begin{array}{c}\text { Vekt } \\
\text { or } \\
\text { Eige } \\
\text { n }\end{array}$ \\
\hline
\end{tabular}

\begin{tabular}{|c|c|c|c|c|c|c|}
\hline Gitar & $\begin{array}{c}0,0 \\
77\end{array}$ & $\begin{array}{l}0,0 \\
32\end{array}$ & 0,059 & $\begin{array}{c}0,05 \\
9\end{array}$ & $\begin{array}{c}0,1 \\
43\end{array}$ & $\mathbf{0 , 0 7 4}$ \\
\hline Vocal & $\begin{array}{l}0,2 \\
31 \\
\end{array}$ & $\begin{array}{l}0,0 \\
97 \\
\end{array}$ & 0,059 & $\begin{array}{c}0,05 \\
9 \\
\end{array}$ & $\begin{array}{c}0,1 \\
43 \\
\end{array}$ & 0,118 \\
\hline $\begin{array}{c}\text { Keybo } \\
\text { ard }\end{array}$ & $\begin{array}{l}0,2 \\
31\end{array}$ & $\begin{array}{l}0,2 \\
90\end{array}$ & 0,176 & $\begin{array}{c}0,17 \\
6\end{array}$ & $\begin{array}{l}0,1 \\
43\end{array}$ & $\begin{array}{c}\mathbf{0 , 2 0 3} \\
\mathbf{3 6}\end{array}$ \\
\hline Teater & $\begin{array}{l}0,2 \\
31 \\
\end{array}$ & $\begin{array}{l}0,2 \\
90 \\
\end{array}$ & 0,176 & $\begin{array}{c}0,17 \\
6 \\
\end{array}$ & $\begin{array}{l}0,1 \\
43 \\
\end{array}$ & $\begin{array}{c}0,203 \\
39 \\
\end{array}$ \\
\hline Tari & $\begin{array}{c}0,2 \\
31 \\
\end{array}$ & $\begin{array}{l}0,2 \\
90 \\
\end{array}$ & 0,529 & $\begin{array}{c}0,52 \\
9 \\
\end{array}$ & $\begin{array}{l}0,4 \\
29 \\
\end{array}$ & 0,402 \\
\hline \multicolumn{6}{|c|}{ Jumlah } & 1 \\
\hline
\end{tabular}

Tabel 12. Eigen Kriteria Aktif

\begin{tabular}{|c|c|c|c|c|c|c|}
\hline Aktif & $\begin{array}{l}\text { Git } \\
\text { ar }\end{array}$ & $\begin{array}{l}\text { Voc } \\
\text { al }\end{array}$ & $\begin{array}{c}\text { Keybo } \\
\text { ard }\end{array}$ & $\begin{array}{l}\text { Teat } \\
\text { er }\end{array}$ & $\begin{array}{c}\text { Tar } \\
\mathrm{i}\end{array}$ & $\begin{array}{c}\text { Vekt } \\
\text { or } \\
\text { Eige } \\
\text { n }\end{array}$ \\
\hline Gitar & $\begin{array}{l}0,4 \\
29 \\
\end{array}$ & $\begin{array}{l}0,5 \\
14 \\
\end{array}$ & 0,529 & $\begin{array}{c}0,27 \\
3 \\
\end{array}$ & $\begin{array}{c}0,3 \\
00\end{array}$ & $\begin{array}{c}0,40 \\
9\end{array}$ \\
\hline Vocal & $\begin{array}{l}0,1 \\
43\end{array}$ & $\begin{array}{l}0,1 \\
71\end{array}$ & 0,176 & $\begin{array}{c}0,27 \\
3\end{array}$ & $\begin{array}{l}0,2 \\
00\end{array}$ & $\begin{array}{c}\mathbf{0 , 1 9} \\
3\end{array}$ \\
\hline $\begin{array}{c}\text { Keybo } \\
\text { ard }\end{array}$ & $\begin{array}{l}0,1 \\
43 \\
\end{array}$ & $\begin{array}{l}0,1 \\
71 \\
\end{array}$ & 0,176 & $\begin{array}{c}0,27 \\
3 \\
\end{array}$ & $\begin{array}{c}0,3 \\
00 \\
\end{array}$ & $\begin{array}{c}0,21 \\
3 \\
\end{array}$ \\
\hline Teater & $\begin{array}{l}0,1 \\
43 \\
\end{array}$ & $\begin{array}{l}0,0 \\
57\end{array}$ & 0,059 & $\begin{array}{c}0,09 \\
1 \\
\end{array}$ & $\begin{array}{l}0,1 \\
00 \\
\end{array}$ & $\begin{array}{c}\mathbf{0 , 0 9} \\
0\end{array}$ \\
\hline Tari & $\begin{array}{l}0,1 \\
43\end{array}$ & $\begin{array}{l}0,0 \\
86\end{array}$ & 0,059 & $\begin{array}{c}0,09 \\
1\end{array}$ & $\begin{array}{c}0,1 \\
00 \\
\end{array}$ & $\begin{array}{c}0,09 \\
6\end{array}$ \\
\hline \multicolumn{6}{|c|}{ Jumlah } & 1 \\
\hline
\end{tabular}

Tabel 13. Eigen Kriteria Potensi

\begin{tabular}{|c|c|c|c|c|c|c|}
\hline $\begin{array}{c}\text { Poten } \\
\text { si }\end{array}$ & $\begin{array}{l}\text { Git } \\
\text { ar }\end{array}$ & $\begin{array}{l}\text { Vo } \\
\text { cal }\end{array}$ & $\begin{array}{c}\text { Keybo } \\
\text { ard }\end{array}$ & $\begin{array}{l}\text { Tea } \\
\text { ter }\end{array}$ & $\begin{array}{c}\text { Tar } \\
\mathrm{i}\end{array}$ & $\begin{array}{c}\text { Vekt } \\
\text { or } \\
\text { Eige } \\
\text { n }\end{array}$ \\
\hline Gitar & $\begin{array}{l}0,4 \\
29 \\
\end{array}$ & $\begin{array}{l}0,5 \\
29 \\
\end{array}$ & 0,529 & $\begin{array}{c}0,23 \\
1 \\
\end{array}$ & $\begin{array}{c}0,2 \\
90 \\
\end{array}$ & $\mathbf{0 , 4 0 2}$ \\
\hline Vocal & $\begin{array}{l}0,1 \\
43\end{array}$ & $\begin{array}{l}0,1 \\
76\end{array}$ & 0,176 & $\begin{array}{c}0,23 \\
1\end{array}$ & $\begin{array}{l}0,2 \\
90\end{array}$ & $\begin{array}{c}\mathbf{0 , 2 0 3} \\
39\end{array}$ \\
\hline $\begin{array}{c}\text { Keybo } \\
\text { ard }\end{array}$ & $\begin{array}{c}0,1 \\
43 \\
\end{array}$ & $\begin{array}{l}0,1 \\
76 \\
\end{array}$ & 0,176 & $\begin{array}{c}0,23 \\
1\end{array}$ & $\begin{array}{c}0,2 \\
90\end{array}$ & $\begin{array}{c}0,203 \\
36\end{array}$ \\
\hline Teater & $\begin{array}{c}0,1 \\
43\end{array}$ & $\begin{array}{c}0,0 \\
59\end{array}$ & 0,059 & $\begin{array}{c}0,07 \\
7\end{array}$ & $\begin{array}{l}0,0 \\
32\end{array}$ & 0,074 \\
\hline Tari & $\begin{array}{c}0,1 \\
43 \\
\end{array}$ & $\begin{array}{l}0,0 \\
59 \\
\end{array}$ & 0,059 & $\begin{array}{c}0,23 \\
1 \\
\end{array}$ & $\begin{array}{c}0,0 \\
97 \\
\end{array}$ & 0,118 \\
\hline \multicolumn{6}{|c|}{ Jumlah } & 1 \\
\hline
\end{tabular}

\section{Menghitung Consistensy Index (CI) dan Consistensy Ratio (CR)}

\subsection{Berdasarkan Kriteria Utama}

Perhitungannya yaitu:

Lamda maks $=(2,676 \times 0,366)+(2,676 \times$ $0,363)+(16,333 \quad x \quad 0,078)+(7,667 \quad x$

$0,144)+(19,000 \times 0,049)=5,26$ 


$$
\begin{aligned}
& \mathrm{CI}=(5,26-5) /(5-1)=0,07 \\
& \mathrm{CR}=0,07 / 1,12=0,058
\end{aligned}
$$

\subsection{Berdasarkan Kriteria Kehadiran}

Perhitungannya yaitu:

Lamda maks $=(3,833 \times 0,256)+(12,000 \times$ $0,083)+(8,333 \quad \mathrm{x} \quad 0,145)+(2,999 \quad \mathrm{x}$ $0,336)+(6,333 \times 0,180)=5,34$

$\mathrm{CI}=(5,34-5) /(5-1)=0,08$

$\mathrm{CR}=0,08 / 1,12=0,08$

\subsection{Berdasarkan Kriteria Kerajinan}

Perhitungannya yaitu:

Lamda maks $=(4,333 \times 0,244)+(7,000 \times$ $0,156)+(7,000 \quad x \quad 0,1500)+(3,666 \quad x$ $0,301)+(7,000 \times 0,1501)=5,35$

$\mathrm{CI}=(5,35-5) /(5-1)=0,09$

$\mathrm{CR}=0,09 / 1,12=0,08$

\subsection{Berdasarkan Kriteria Fokus}

Perhitungannya yaitu:

Lamda maks $=(13,000 \times 0,074)+(10,333 \times$ $0,118)+(5,666 \quad \mathrm{x} \quad 0,20336)+(5,666 \quad \mathrm{x}$ $0,20339)+(2,333 \times 0,402)=5,42$

$\mathrm{CI}=(5,42-5) /(5-1)=0,10$

$\mathrm{CR}=0,10 / 1,12=0,09$

\subsection{Berdasarkan Kriteria Aktif}

Perhitungannya yaitu:

Lamda maks $=(2,333 \times 0,409)+(5,833 \times$ $0,193)+(5,666 \quad \mathrm{x} \quad 0,213)+(11,000 \quad \mathrm{x}$ $0,090)+(10,000 \times 0,096)=5,23$

$\mathrm{CI}=(5,23-5) /(5-1)=0,06$

$\mathrm{CR}=0,06 / 1,12=0,05$

\subsection{Berdasarkan Kriteria Potensi}

Perhitungannya yaitu:
Lamda maks $=(2,333 \times 0,402)+(5,666 \times$ $0,20339)+(5,666 \quad \mathrm{x} \quad 0,20336)+(13,000 \times$ $0,074)+(10,333 \times 0,118)=5,42$

$\mathrm{CI}=(5,42-5) /(5-1)=0,10$

$\mathrm{CR}=0,10 / 1,12=0,08$

E. Menghitung Vektor Eigen Keputusan Vektor eigen keputusan alternatif gitar $=$ $(0,256 \times 0,366)+(0,244 \times 0,363)+(0,074 \times$ $0,078)+(0,409 \times 0,144)+(0,402 \times 0,049)$ $=0,266$

Vektor eigen keputusan alternatif vocal $=$ $(0,083 \times 0,366)+(0,156 \times 0,363)+(0,118 \times$ $0,078)+(0,193 \times 0,144)+(0,203 \times 0,049)$ $=0,134$

Vektor eigen keputusan alternatif keyboard $=$

$(0,145 \times 0,366)+(0,150 \times 0,363)+(0,203 \times$ $0,078)+(0,213 \times 0,144)+(0,203 \times 0,049)$ $=0,164$

Vektor eigen keputusan alternatif teater $=$ $(0,336 \times 0,366)+(0,301 \times 0,363)+(0,203 \times$ $0,078)+(0,090 \times 0,144)+(0,074 \times 0,049)$ $=0,264$

Vektor eigen keputusan alternatif tari $=$ $(0,180 \times 0,366)+(0,150 \times 0,363)+(0,402 \times$ $0,078)+(0,096 \times 0,144)+(0,118 \times 0,049)$ $=0,171$

Dari vektor eigen keputusan terlihat bahwa:

A. Gitar memiliki bobot prioritas tertinggi yaitu 0,266

B. Teater memiliki bobot prioritas kedua yaitu 0,264

C. Tari memiliki bobot prioritas ketiga yaitu 0,171

D. Keyboard memiliki bobot prioritas keempat yaitu 0,164

E. Vocal memiliki bobot prioritas terendah yaitu 0,134 
Bila digambarkan dalam bentuk grafik maka dapat dilihat jumlah presentasenya sebagai berikut:

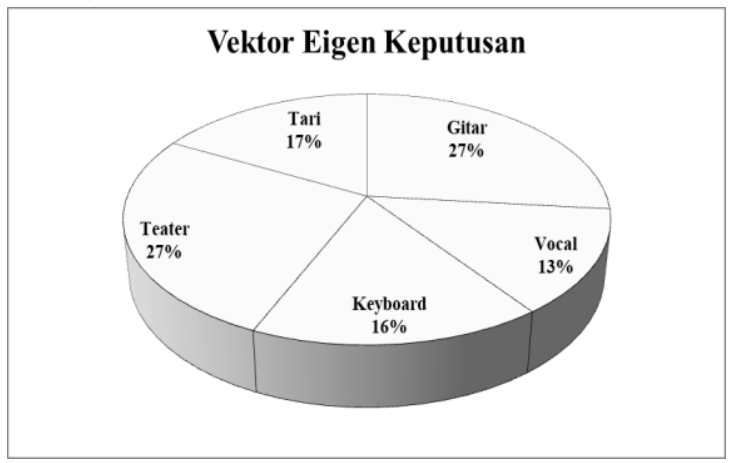

Gambar 5. Presentase Keputusan

\section{Hasil Implementasi dengan Software Expert Choice 11}

Hasil dari data-data kuesioner diinput dengan menggunakan software Expert Choice Versi 11 yang hasilnya dapat dilihat pada gambar berikut:

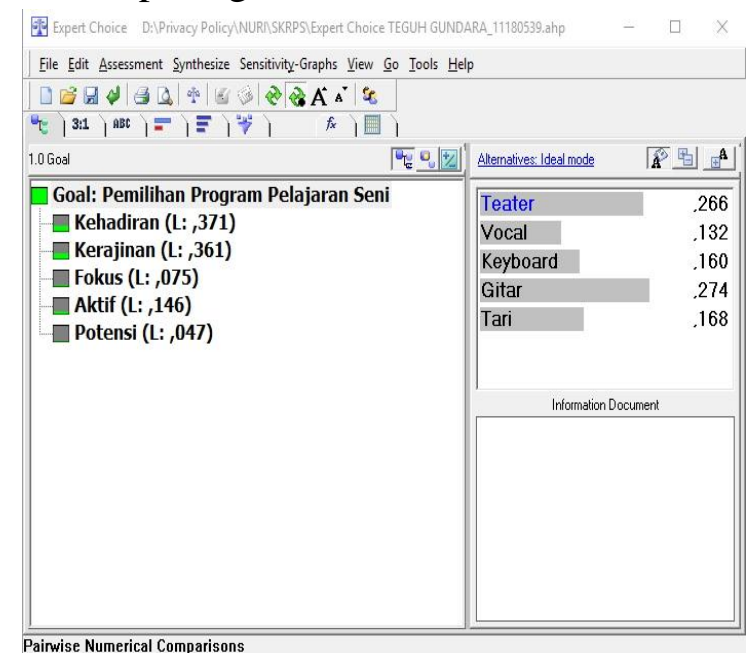

Gambar 6. Hasil Pengolahan Data Kuisioner

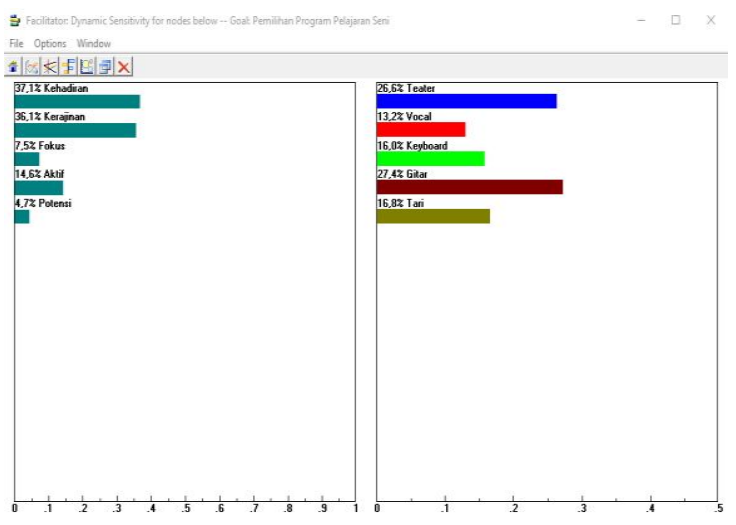

Gambar 7. Presentase Keseluruhan

Dari hasil perhitungan dengan software Expert Choice 11 menunjukkan bahwa:

1.Gitar memiliki bobot presentase tertinggi yaitu $27,4 \%$

2.Teater memiliki bobot presentase kedua yaitu $26,6 \%$

3.Tari memiliki bobot presentase ketiga yaitu $16,8 \%$

4.Keyboard memiliki bobot presentase keempat yaitu $16 \%$

5.Vocal memiliki bobot presentase terendah yaitu $13,2 \%$

\section{Hasil Perbandingan Perhitungan Manual dengan Expert Choice}

Hasil perhitungan manual dengan Expert Choice tidak memiliki perbedaan yang terlalu besar, adapun perbedaan untuk hasil perhitungannya sebagai berikut:

A. Presentase urutan prioritas pelajaran seni gitar manual $27 \%$ menggunakan EC $27,4 \%$, pelajaran seni teater manual $27 \%$ menggunakan EC 26,6\%, pelajaran seni tari manual $17 \%$ menggunakan EC 16,8\%, pelajaran seni keyboard manual $16 \%$ menggunakan EC $16,0 \%$, pelajaran seni vocal manual $13 \%$ menggunakan EC 13,2\%.

B. Perhitungan secara manual memilih pelajaran seni gitar sebagai prioritas utama, begitupun dengan perhitungan menggunakan Expert Choice.

\section{KESIMPULAN}

1. Berdasarkan hasil perhitungan pada tabel kriteria di atas menunjukkan bahwa:

A. Kriteria kehadiran memiliki prioritas tertinggi dengan bobot 0,366

B. Kriteria kerajinan memiliki prioritas kedua dengan bobot 0,363 
C. Kriteria aktif memiliki prioritas ketiga dengan bobot 0,144

D. Kriteria fokus memiliki prioritas keempat dengan bobot 0,078

E. Kriteria potensi memiliki prioritas terendah dengan bobot 0,049

Nilai-nilai tersebut menjelaskan bahwa kehadiran adalah prioritas terpenting.

2. Sedangkan untuk alternatif pelajaran seni berdasarkan perhitungan di atas menunjukkan bahwa:

A. Gitar memiliki bobot prioritas tertinggi yaitu 0,266

B. Vocal memiliki bobot prioritas kedua yaitu 0,264

C. Teater memiliki bobot prioritas ketiga yaitu 0,171

D. Keyboard memiliki bobot prioritas keempat yaitu 0,164

E. Tari memiliki bobot prioritas terendah yaitu 0,133

Maka dengan demikian prioritas pemilihan pelajaran seni yang dilakukan responden yaitu pelajaran seni gitar sebagai prioritas tertinggi

\section{Saran}

Berdasarkan hasil penelitian yang telah dilakukan, maka saran-saran yang dapat peneliti berikan adalah:

1. Penerapan sistem penunjang keputusan dengan metode Analytic Hierarchy Process (AHP) ini diharapkan dapat diterapkan untuk bidang mata pelajaran lain yang ada di SD Al-Fath Cirendeu, atau bisa juga diterapkan pada tingkat Taman Kanak-Kanan (TK Al-Fath Cirendeu) maupun tingkat Sekolah Menengah Pertama (SMP Al-Fath Cirendeu) sehingga dengan adanya metode ini tidak hanya membantu guruguru pelajaran seni SD saja tapi dapat membantu seluruh guru dan siswa di lingkungan Sekolah Al-Fath baik TK, SD maupun SMP.

2. Selain pengolahan data Dengan menggunakan metode Analytic Hierarchy Process (AHP) data-data tersebut bisa juga diolah Dengan menggunakan metode lain seperti metode Analytic Network Process (ANP), Technique for Order by Similarity to Ideal Solution (Topsis), Simple Additive Weighting $(S A W)$, dan masih banyak lagi metode sistem penunjang keputusan.

\section{DAFTAR PUSTAKA}

Agustini, F. (2018). Penerapan Metode AHP Pada Pemilihan Kosmetik Yang Tepat Untuk Siswi SMA. Swabumi 6(2), 165-173.

Danang \& Nisar, (2017). Sistem Pendukung Keputusan Pemilihan PTS Jurusan Komputer Menggunakan Metode AHP di Kota Semarang. Simetris, 8(1), 45-52.

Darmanto, E., Latifah, N., \& Susanti, N. (2014). Penerapan Metode AHP (Analytic Hierarchy Process) Untuk Menentukan Kualitas Gula Tumbu. Simetris, 5(1), 75-82.-

Nurmalasari \& Pratama, A. A. (2018). Sistem Pendukung Keputusan Pemilihan Supplier Menggunakan Metode AHP Pada PT. Transcoal Pacific Jakarta. Teknik Komputer AMIK BSI IV(2). https://doi.org/10.31294/jtk.v4i2.3509 